\title{
"Keeping the Political Fires Burning": Republican Women's Clubs and Female Political Culture in Small-Town Iowa, 1928-1938
}

\section{CATHERINE E. RYMPH}

IN 1928 Iowa Republicans were eager to elect their native son, Herbert Hoover, to the presidency. On August 17, sixty-oneyear-old Ella Taylor of Traer organized a meeting of twelve fellow members of the Women's Division of the Tama County Republican Central Committee to explore means of tapping that enthusiasm among women. Taylor and her associates formed the Tama County Republican Women's Club and elected Mae Banks (a Republican precinct committeewoman from Montour) as president. A month later, at the Princess Theatre in Traer, 56 women met and decided to make their club a "permanent institution in the political life of Tama County." The members endorsed Herbert Hoover for president, applauded when Republican National Committeewoman Martha McClure urged them to use their votes, and joined in singing several Hoover campaign songs. ${ }^{1}$

An earlier version of this paper was presented at the Iowa Heritage Expo, June 15,1996 . I am grateful to the Iowa Sesquicentennial Commission for financial support; to Joyce Wiese for making her scrapbooks available to me; and to Linda Kerber, Michael Strübin, and the anonymous readers for the Annals of Iowa for their thoughtful comments and criticism.

1. Tama News Herald, 23 August 1928, 13 September 1928. The 60-year-old McClure, a Mt. Pleasant native, served as Iowa National Committeewoman from 1928 until she died in 1945. Des Moines Register, 18 August 1945. The Re-

THE ANNALS OF IOWA 56 (Winter/Spring 1997). CThe State Historical Society of Iowa, 1997. 
During the next month, Taylor and Banks held similar meetings in libraries, theaters, and homes throughout the county. On October 17, more than one hundred Republican women (and some men) braved a downpour to attend a countywide rally and covered dish supper at Toledo, the county seat. During the afternoon, the Toledo orchestra and the Toledo women's glee club entertained the audience. The featured speaker, Congressman Cyrenus Cole, scolded women for their lack of interest in politics, and implored them to use their votes to influence "every moral movement." Mrs. L. E. Jackson, Fifth District Republican Vice-Chairman, retorted that men's unwillingness to accept women into their "political confidence" had discouraged women's interest in political matters. Jackson was sure, however, that the moral issues involved in the current campaign would "rouse the women to action as never before." At a business meeting following the rally, club leaders learned that the Tama County club movement had already attracted 568 members. ${ }^{2}$

In these early meetings, the Tama County GOP clubwomen were not only working to elect Hoover. In a larger sense, they were attempting to address some of the persistent obstacles to

publican National Committeewoman from each state was the female counterpart to the National Committeeman. In 1924 the all-male Republican National Committee added these positions to its body as a result of woman suffrage. (The Democratic Party had made a similar change in 1920.) In many states, counties, and precincts (although not everywhere, and at varying times), the positions of "co-chairman" and "vice-chairman" were created and filled by female counterparts to local male leadership. For general discussions of the ways the two parties accommodated woman suffrage, see J. Stanley Lemons, The Woman Citizen: Social Feminism in the 1920s (Urbana and Chicago, 1973), 85-116; and Kristi Andersen, After Suffrage: Women in Partisan and Electoral Politics before the New Deal (Chicago, 1996), 77-109.

2. Tama News Herald, 18 October 1928; "130 Hear G.O.P. Speakers at Toledo Depite [sic] Bad Roads," clipping, 17 October 1928, Tama County Republican Women Scrapbook. I thank Joyce Wiese for making this scrapbook and the Third District Republican Women Scrapbook available to me. A significant amount of information for this article comes from such scrapbooks. Although they are not ideal sources, scrapbooks, which typically consist of newspaper clippings, photographs, and brochures, are often the only places where material on women's organizations is collected. Women's letters and the official records of women's organizations have not always been preserved and archived, and the correspondence of male political leaders typically contains few references to women's activities. 
women's full political participation that the ratification of the woman suffrage amendment eight years earlier had not eradicated. American women had secured the right to vote in August 1920, but the formal institutions and the informal culture of American partisan politics remained decidedly male provinces. ${ }^{3}$

In forming Republican women's clubs, party regulars Taylor and Banks created women-centered political spaces where ordinary women who were not part of the official party organization but who had Republican leanings could gain the information about political issues that they needed in order to be interested and confident enough to vote. To activate the indifferent, Taylor and other leaders portrayed women's Republican activism as an urgent crusade that women alone could lead. In their clubs, women developed a new female political culture that combined elements of traditional middle-class women's clubs with partisan politics. In promoting the integration of women into the political life of local communities, Republican women's clubs also had the potential to reshape local political culture and to move women into the center of party affairs. This effort had its roots in an older female political culture developed at a time when women were shut out of active participation in partisan politics.

IN THE FALL OF 1936, the Jefferson Bee printed a nostalgic recollection of the parades, banners, and bands of nineteenthcentury political campaigns. "While political campaigns are still waged with vigor, and are often enlivened with spectacular

3. In her study of gender and politics in rural New York from the mid-nineteenth century to the decade after woman suffrage, Paula Baker concludes that in the 1920s "manhood and womanhood became private matters defined and contested outside of politics, not traits represented in public life." I disagree. Although definitions of what was political and who could participate (and on what terms) changed significantly as a result of woman suffrage, gender continued to be a critical marker of political behavior. Kristi Andersen argues that an important outcome of woman suffrage was that gender boundaries were redrawn: one boundary defining political rights and appropriate political behavior (women's exclusion from suffrage) was eliminated, but new boundaries (women were less likely to serve in national politics than in local and state politics and were supposed to be interested in "women's issues," for example) were drawn. Paula Baker, The Moral Frameworks of Public Life: Gender, Politics, and the State in Rural New York, 1870-1930 (New York, 1991), 175; Andersen, After Suffrage. 
oratory," the Bee's writer noted, "they do not compare in picturesqueness and enthusiasm with those of the old days." This piece inspired a response from Ella Taylor. Commenting on the Bee's wistful reminiscences in her regular women's column in the Traer Star-Clipper, Taylor recalled old-time political parades in Traer, complete with elaborate floats, headed by the Traer band, and followed by torch bearers. The men, she remembered, wore red oil-cloth capes with blue collars and red and blue military caps. "Of course," Taylor wrote with a sarcasm that was typical of her writings on women's exclusion from politics, "there were no women because it was in the days when the women were classed with the Indians and idiots." In those days, she recalled, every schoolhouse held a political meeting during the weeks before an election at which speakers and debaters addressed the issues of the campaign. Taylor had begged her husband to take her to one of these meetings, but women were not welcome. "Why should they [be]?" Taylor asked rhetorically. "They couldn't vote and they only took up room that ought to be given to a voter."

Most historians have echoed Taylor's depiction of nineteenthcentury partisan politics as steeped in male rituals from which women generally were excluded. Paula Baker, for example, has described nineteenth-century political parties as locally based "fraternal organizations that tied men together with others like

4. Ella Taylor, "Old Time Campaigns," Traer Star-Clipper, 23 October 1936, (which quoted the earlier Jefferson Bee article), Tama County Republican Women Scrapbook. Taylor's women's columns, although unattributed, are easily identified as her own, due to her recognizable tone and manner of referring to herself with the plural "we." Her columns offer a good insight into her thinking. They are opinionated, revealing her forceful personality and humor as she chronicles the fortunes of the Republican Party and the Republican women's club movement, noting failures as well as successes. Dates for the columns are handwritten next to the clippings, so they may not be precisely accurate in all cases. Other newspaper clippings in this and other Republican women's scrapbooks are not always identified by date and source, although they appear in general chronological order. Because the scrapbooks loaned to me by Joyce Wiese are copies of Ella Taylor's originals, most of the clippings seem to be from the Traer Star-Clipper (which Ella Taylor ran with her husband), although other newspapers are included as well. When the name of the newspaper is given or implied, I have used it. When unsure, I have simply referred to articles as "clippings." 
themselves in their communities." Reading partisan newspapers, attending rallies, displaying campaign buttons and other partisan symbols, and marching in parades, according to Baker, had provided white men with "entertainment, a definition of manhood, and the basis for a male ritual. ${ }^{15}$ Through local partisan culture, a man came to believe that his party belonged to him; that the party embodied himself and people like him.

Historians have generally characterized women's participation in nineteenth-century partisan culture as passive. Party activity took place in male spaces such as saloons, barbershops, and middle-class social clubs from which women were excluded, either explicitly or by convention. Even when women were present at parades or rallies, they were usually there as spectators or were employed symbolically as female embodiments of political principles or cultural icons. ${ }^{6}$ Although some historians have pointed to a somewhat greater presence of antebellum women in partisan political activity than had previously been appreciated, the culture of electoral politics in the days before women voted was generally a masculine one. ${ }^{7}$

That is not to say that women, before they could vote, were apolitical. In their voluntary organizations, which exploded in number in the late nineteenth and early twentieth centuries, many American middle-class women pursued their own political agendas and developed their own political culture, with accompanying values, rituals, spaces, and strategies. According to the nineteenth-century doctrine of separate spheres, women's interests and duties properly focused on running households

5. Paula Baker, "The Domestication of Politics: Women and American Political Society, 1780-1920," American Historical Review 89 (1984), 628. See also Arnaldo Testi, "The Gender of Reform Politics: Theodore Roosevelt and the Culture of Masculinity," Journal of American History 81 (1995), 1509-33. The importance of fraternal ritual to notions of Victorian middle-class masculinity is explored in Mark C. Carnes, "Middle-Class Men and the Solace of Fraternal Ritual," in Meanings for Manhood: Constructions of Masculinity in Victorian America, ed. Mark C. Carnes and Clyde Griffen (Chicago, 1990), 37-52.

6. Baker, "Domestication of Politics," 629; Mary Ryan, Women in Public: Between Banners and Ballots, 1825-1880 (Baltimore, 1990).

7. On women's partisanship in the nineteenth century, see for example, Elizabeth R. Varon, "Tippecanoe and the Ladies, Too: White Women and Party Politics in Antebellum Virginia," Journal of American History 82 (1995), 494-521. 
and educating their families regarding religion, morality, and culture. ${ }^{8}$ When women became involved with various broader concerns, such as consumer issues, temperance, or legislation for the protection of women and children, they often justified their involvement as an extension of their home responsibilities: women's responsibilities for keeping their homes in clean, safe, moral order required them, activists argued, to engage in "social housekeeping" as well. ${ }^{9}$ Certainly there was no monolithic women's politics. But the organized women who were active in various causes generally understood themselves as embodying a set of values different from those of men, and they saw their political work as stemming from different impulses. Clubs that were less overtly political, such as charity societies, church groups, literary clubs, and patriotic organizations, embraced similar ideas about women's selflessness and their capacity for alleviating social problems. ${ }^{10}$

The extension of suffrage to women in 1920, then, did not simply increase the numbers of a generic electorate. The national enfranchisement of a segment of Americans believed to hold decidedly different views from existing voters was at least

8. Some historians have seen the rhetoric of separate spheres as proscriptive and oppressive; others have described it as a women-created ideology that was a source of women's power. The classic example of the first view is Barbara Welter, "The Cult of Domesticity: 1820-1860," American Quarterly 18 (1966), 151-74. Carroll Smith-Rosenberg articulated the second view in "The Female World of Love and Ritual: Relations between Women in NineteenthCentury America," Signs 1 (1975), 1-29. Linda Kerber has argued that historians need to take care to distinguish between these different interpretations and, furthermore, not to read the language of separate spheres as a literal description of men's and women's political or social roles. Linda K. Kerber, "Separate Spheres, Female Worlds, Woman's Place: The Rhetoric of Women's History," Journal of American History 75 (1988), 9-39.

9. On female political culture during the nineteenth century, see Baker, "Domestication of Politics," 620-47; and Suzanne Lebsock, "Women and American Politics, 1880-1920," in Women, Politics, and Change, ed. Louise Tilly and Patricia Gurin (New York, 1990), 35-62. On women's voluntarism, see Anne Firor Scott, Natural Allies: Women's Associations in American History (Urbana and Chicago, 1992). On the contrasts between "male" party politics and "female" reform politics, see Testi, "Gender of Reform Politics."

10. For a history of different types of women's clubs, see Anne Firor Scott, Natural Allies: Women's Associations in American History (Urbana and Chicago, 1993). 
potentially volatile enough to have led to party realignment. That possibility encouraged both Democrats and Republicans to work to win women voters into their respective camps. Both major political parties incorporated women into an understanding of politics that defined women as a special class of voters who were marked by their sex and whose incorporation required the reorganization of party institutions. This meant creating separate organizations and budgets for women within the Republican and Democratic National Committees, as well as trying to institute similar changes in state, county, and precinct committees. ${ }^{11}$

Women's votes, however, did not bring a revolution. Newly enfranchised women still had to develop the habit of voting. ${ }^{12}$ Although many American women were politically sophisticated (having played leading roles not only in the suffrage movement but in other Progressive Era movements for social and political reform), the vast majority of American women were uninitiated into formal political activities - voting, campaigning, stumping. Some considered such activities crass and unfeminine while others felt themselves unwelcome in the party organizations. The very idea of political parties and partisan-

11. Women leaders embraced this strategy broadly, although it, in effect, institutionalized women's difference from men. Separate organizations for women meant that women as a whole would continue to be seen as a different class of voters. Yet these organizations also gave ambitious partisan women opportunities to become party leaders that they might not otherwise have had. Eleanor Roosevelt, through her work in the Women's Division of the New York State Democratic Party in the 1920s, developed a strong appreciation for this opportunity. For women to have influence within the party, she insisted, they needed to select political bosses - women leaders who, backed by a constituency of women, held positions within all levels of party organization. For a discussion of Roosevelt's idea of women as political bosses, see Blanche Wiesen Cook, Eleanor Roosevelt, vol. 1, 18841933 (New York, 1992), 338-80.

12. Although contemporary commentators lamented women's failure to fulfill the responsibilities of suffrage, their low turnout was part of a general decline in voter participation since about 1890. Paul Kleppner, "Were Women to Blame? Female Suffrage and Voter Turnout," Journal of Interdisciplinary History 12 (1982), $621-43$. Kristi Andersen demonstrates that voting among women varied considerably from place to place. Although several factors contributed to this variation, Andersen suggests that the most significant was the extent to which local party organizations tried to mobilize women. Andersen, After Suffrage, 49-75. 
ship connoted, for many women, machine politics, corruption, and a distasteful male political culture that promoted blind party loyalty over independence, personal ambition over concern for the public good, and unprincipled pragmatism over ideals. Many suffrage activists thought women would do best to stay out of male political institutions altogether and instead to continue channeling their political activism through women's organizations.

Others, however, feared that voting women would have no real political influence unless they worked within the parties. Partisan women leaders encouraged women's political participation because they were champions of women's political equality. But fierce partisans, such as Ella Taylor, also encouraged Republican women to participate in politics as a way of strengthening the party they supported. ${ }^{13}$ Furthermore, mobilizing a significant segment of the vote provided talented women with an outlet for their political skills and passions. And although most denied being politically ambitious, success in their endeavors had the potential to bring organizers of women a certain amount of clout and respect within the party. ${ }^{14}$

One way that women leaders tried to bring large numbers of women into partisan politics was through women's partisan

13. As Nancy Cott correctly points out, the League of Women Voters and the women's divisions of the Republican and Democratic Parties were all successor organizations to the National American Woman Suffrage Organization (NAWSA) and thus shared the goal of preparing women for political life. In many cases, however, competition for members and the issue of partisanship meant that the partisan organizations became rivals of the League rather than its complements. Nancy F. Cott, The Grounding of Modern Feminism (New Haven, CT, 1987), 86-87.

14. Ella Taylor herself insisted that she had no ambition for public office. In a May 1933 column in which she called on Republican men in the county to overcome their prejudices and nominate a woman to fill a recently vacated local office, Taylor pled "not guilty" to the suggestion that she aspired to the office herself. She perhaps would be willing to do the work of public office, Taylor claimed, but she would never endure the demands of campaigning: she would not "kiss dirty faced babies; slap somebody on the back and call him a good fellow when we know he isn't; . . . advocate a lot of things we know are 'the bunk'; promise fellows jobs whom we know aren't fitted for the place; ... and ... go about from door to door interviewing the housewives when they ought to be washing their breakfast dishes." Ella Taylor, "Read It Again," Traer StarClipper, 19 May 1933, Tama County Republican Women Scrapbook. 
clubs. ${ }^{15}$ To develop partisanship, ordinary women needed to experience their party as something that belonged to them, and as something with which they could identify. Partisan clubs, by embracing the techniques, values, and traditions of existing women's clubs, could serve that purpose.

NINETEEN TWENTY-EIGHT brought a nationwide surge in the formation of Republican women's clubs and women's Hoover clubs. Dismayed by the lack of interest women had shown in the 1924 election, the Women's Division of the Republican National Committee (RNC) set out in 1928 to target women voters specifically. Under the direction of Mrs. Silas Strawn, the Women's Division organized 15-minute radio broadcasts intended for women. Strawn encouraged "radio hostesses" to hold parties where women would gather in their homes to listen to and discuss radio broadcasts of speeches by GOP leaders. The radio talks were to be "in the nature of 'political gossip" and of "particular interest to women. ${ }^{16}$ Thus when Ella Taylor began organizing Republican women's clubs in her county, other women across the country were making similar efforts to

15. Republican women's clubs began developing even before 1920 . Some clubs were officially linked to state Republican organizations. Others remained proudly independent of the official party. By 1929, statewide networks of independent Republican women's clubs were well established in Delaware, Illinois, Maryland, Massachusetts, New Jersey, New York, and Pennsylvania, and were developing in Indiana, Kentucky, Michigan, and Ohio. "Mr. Hoover Approves Independent Republican Clubs," The Republican Woman [newsletter of the Republican Women of Pennsylvania], January 1929, Scrapbook 1929, Republican Women of Pennsylvania Records, Historical Society of Pennsylvania, Philadelphia. For a treatment of one such club movement, see relevant parts of Felice Gordon, After Winning: The Legacy of the New Jersey Suffragists, 1920-1947 (New Brunswick, NJ, 1986). In 1924 black Republican women established a national network of Republican clubs, the National League of Republican Colored Women. Evelyn Brooks Higginbotham, "In Politics to Stay: Black Women Leaders and Party Politics in the 1920s," in Women, Politics, and Change, 208-12. Democratic women leaders also established partisan women's clubs. See Andersen, After Suffrage, 87. It appears, however, that explicitly partisan women's clubs did not catch on with Democratic women to the extent that they did with their Republican counterparts.

16. Republican Daily News [publication of the Republican National Committee], 20 September 1928, Republican National Committee-Daily News 7/23/289/20/28 file, box 162, Campaign and Transition Collection, Herbert Hoover Papers, Herbert Hoover Presidential Library, West Branch, Iowa. 
combine political and social activities as a strategy for attracting women to partisan politics.

In 1928 the Republicans nominated a candidate for the presidency who seemed to appeal especially to many women. ${ }^{17}$ GOP pamphlets targeting women presented Herbert Hoover as a candidate whose principles were more female than male: Hoover had shown himself to be a humanitarian through his relief efforts in Europe after World War I, and he was against Tammany Hall and liquor interests. Indeed, these pamphlets alleged, Hoover wasn't even a politician at all; he was a disinterested citizen above politics. Those in charge of the women's campaign intended this latter claim as a powerful selling point with women believed to be wary of party regularity. ${ }^{18}$ In Tama County, Mae Banks emphasized to women Hoover's belief in "the inherent right of every mother to protect her children from the nullification of the eighteenth [prohibition] amendment"; Hoover's background as a bona fide farm boy and a current farm operator (while Al Smith did not even own "a deed to a cabbage patch"); and Smith's links to machine politics. ${ }^{19}$

Hoover carried 93 of 99 Iowa counties in 1928, winning 62 percent of the Iowa vote. The extent to which women's support

17. Middle-class, Protestant clubwomen supported Hoover enthusiastically, but many of the numerous recently naturalized immigrant women who entered the electorate that year voted Democratic. Andersen, After Suffrage, 72-73.

18. "Why American Home Women Want Hoover," Women's Club Publications, 1931-2, and undated file, box 274, Presidential Subject Files, Hoover Papers. See also "What Every Woman Wants to Know about the Tariff" and "We Women Want Hoover," 1928, Campaign: Literature file, box 179, Campaign and Transition Collection, Hoover Papers; Republican Daily News, 12 September 1928, Republican National Committee-Daily News 7/23-9/20/28 file, box 162, ibid.

19. "Mrs. L. Mae Banks Urges Farm Women to Vote for Hoover," Traer StarClipper, 2 November 1928, Tama County Republican Women Scrapbook. While Banks tried to portray Hoover as a friend of the farmer, most midwestern farm leaders, including Progressive Republicans, were critical of Hoover's opposition to the McNary-Haugen Farm Relief Bill (which would have provided government price supports for key agricultural products), and saw Hoover as more the friend of industry than of the farmer. Gilbert C. Fite, "The Agricultural Issue in the Presidential Campaign of 1928," Mississippi Valley Historical Review 37 (1951), 657. National Democratic women leaders, in selling Smith to women voters, emphasized Smith's support for reform measures advocated by many women's organizations and his willingness to oppose big business for the common good. Cook, Eleanor Roosevelt, 373-74. 
played a role in Hoover's victory is difficult to assess. Anecdotal evidence suggests that there was at least a perception that women's role was significant. Pre-election straw polls conducted by the Des Moines Register indicated that Hoover's support among women was particularly strong. And the chairman of the Democratic State Central Committee blamed Smith's defeat in Iowa on the state's women. ${ }^{20}$

Taylor and Banks had formed their club to work for Hoover's victory, but they did not see their task as ending on election day. Turning women into active partisans required more than a temporary campaign club; it required a permanent organization that would serve to fuse partisanship with women's day-to-day lives. After Hoover's election, the Tama County Republican Women's Club did not disband as campaign clubs usually did, but remained active. One year later, at a picnic luncheon celebrating its first anniversary, the county club claimed 1,200 members. ${ }^{21}$

In general, Republican clubwomen were probably older, native-born Protestant women who had some education, lived in or near small towns, were active in other women's organizations, and had family ties to the Republican Party. ${ }^{22}$ Active clubwomen who attended meetings regularly probably lived in

20. Alan Jones, "The New Deal Comes to Iowa," in The New Deal Viewed from Fifty Years: Papers Commemorating the Fiftieth Anniversary of the Launching of President Franklin D. Roosevelt's New Deal in 1933, ed. Lawrence E. Gelfand and Robert J. Neymeyer (Iowa City, 1983), 29; Jason K. Duncan, "Tammany Farmer: Al Smith and the 1928 Presidential Campaign in Iowa," unpublished paper (University of Iowa, 1993), 24, available at State Historical Society of Iowa, Iowa City.

21. Ella Taylor, Speech, ca. 1937, History Book 1937-1956, box 1, Iowa Council of Republican Women Records, State Historical Society of Iowa, Iowa City (hereafter cited as ICRW records). The ICRW Records consist almost entirely of scrapbooks. The first of these, covering the period 1937-1956, begins with a series of unattributed speeches. Based on the manner in which these speeches are presented in the scrapbook (preceding a tribute to Ella Taylor) and on the way the writer refers to herself and her activities, I am confident that these speeches were made by Taylor.

22. No detailed profile of the membership of Iowa Republican women's clubs is available, but Alan Jones's general sketch of Republican voters in Iowa in the thirties suggests that Republican voters generally were native born and Protestant and typically dwelt in small towns and cities (of more than 1,000 but fewer than 10,000 residents). Jones, "The New Deal Comes to Iowa," 21-53. 
or near the small towns of Tama County, the largest of which were Traer (with a population of 1,417 in 1930), Toledo $(1,825)$, and Grundy Center $(1,793) .{ }^{23}$ Dividing the county's Republican women into small local clubs was necessary because bad roads and a lack of women drivers made it difficult to hold frequent county-wide meetings. Judging from photographs in Taylor's scrapbooks, most of the Tama County club leaders were older than fifty, and some were much older. Profiles of Republican clubwomen that appeared in newspapers indicated that many were also members of the American Legion Auxiliary, the Red Cross, and Business and Professional Women. Ella Taylor and Mae Banks were both college educated and had worked at professions, Taylor as a writer and Banks, for a while, as a teacher. Both were married to prominent and active Republican men. ${ }^{24}$

Taylor and Banks continued organizing local units in the various towns and townships across the county, encouraging

23. U.S. Bureau of the Census, Fifteenth Census of the United States: 1930, vol. 1, Population (Washington, DC, 1951), 50.

24. Ella Canfield was born April 1, 1867, in Vermont and was educated at Coe College in Iowa. In 1887 she married Elmer E. Taylor of Traer, who in addition to being managing editor of the weekly Traer Star (later Star-Clipper), was also a director of the First National Bank of Traer. Ella Taylor was the editor of the women's department of the Traer Star-Clipper, wrote a weekly column for the woman's page, and contributed to other magazines and periodicals. In addition to her Republican activities, she was active in the Traer Business and Professional Women and the Iowa Press Women's Club. She was a member of the Congregational church and had two sons. The Iowa Press Association's Who's Who in Iowa (Des Moines, 1940), 1168-69. L. Mae Fellows was a native of Montour and a graduate of Iowa State College at Ames. She worked as a teacher before her marriage to A. J. Banks. The couple farmed outside Montour until A. J. Banks, a one-time Republican candidate for governor, died in 1939. Like Taylor, Banks was also a member of the Congregational church. She was involved with Red Cross work during World War I. In the 1920s Mae Banks served as precinct committeewoman in her township and later as county vice-chairman. In 1934 she became a member of the Republican State Central Committee, and in 1940 was an unsuccessful candidate for clerk of the District Court. In 1941 Republican Governor George A. Wilson appointed her to a position with the State Board of Control. She later took a job with the federal government in Washington, DC. In 1953 she remarried and moved to Arkansas with her husband. "Mrs. Banks Accepts Nomination as Clerk," Traer Star-Clipper, 2 August 1940; "Mrs. Banks Wins Promotion," ibid., 10 April 1942; "Mrs. Banks Back," ibid., 11 May 1951, Tama County Republican Women Scrapbook; Anna Putnam, Speech, ca. 1953, History Book 1937-1956, box 1, ICRW Records. 
the clubs to hold regular meetings throughout the year. Organization appeared to be proceeding well. Taylor believed that a large percentage of Tama County's Republican women voted in the 1930 mid-term elections because of "the women's excellent organization. ${ }^{25}$ By 1931, the Executive Committee of the Tama County Republican Women's Club was sending monthly bulletins to presidents of local units with suggestions for programs and activities. They encouraged the inclusion of patriotic music and skits as parts of meetings whose programs were to focus on foreign policy issues (the World Court), domestic issues (the education bill, the income tax), local issues (the financing of local schools), and issues of particular interest to women (the citizenship of married women, jury duty for women, mother's pensions). ${ }^{26}$

Although Republican women's clubs focused on mobilizing women, their reach was broader. At a July 1931 countywide Republican meeting organized by the Republican Women's Club, for example, the 75 men and women who attended enjoyed speeches by Republicans as well as a prayer by a local clergyman, community singing of patriotic songs, a demonstration by the Tama Boy Scouts on the proper use of the flag, and a talk on the American Legion by one of its members. ${ }^{27}$ These kinds of events held in nonelection years fused politics with other family-oriented activities that appealed to the conservative sensibilities of Republican attendees. Clubs also held pre-primary candidate forums for the general public that gave all voters the opportunity to acquaint themselves with candidates and issues.

The Republican Party again embarked on national campaigns targeting women during Hoover's reelection bid in 1932. Many of the campaign's appeals to women were similar to those

25. "Tama County Republican Women's Club Continues to Grow Steadily," 1930, clipping in Tama County Republican Women Scrapbook. Taylor's assertions about women's voting behavior (how many voted and why they did so) cannot be confirmed, of course. Her observations do, however, provide a sense of her own perceptions of the club movement's development.

26. Ella Taylor, "Course of Study," Traer Star-Clipper, 11 September 1931, Tama County Republican Women Scrapbook.

27. "County Republican Picnic Attracts 75," 7 July 1931, clipping, Tama County Republican Women Scrapbook. 
used in 1928. "Women trust and believe in Herbert Hoover," declared Mrs. Bina West Miller in a nationally released campaign statement. "They know of his great work for women and children and non-combatants in the World War. They helped save food for him, that the helpless could be fed." 28 By 1932, however, the country was in the midst of economic depression. Such rhetoric did not resonate so broadly. Undoubtedly in response to that reality, the women's campaign also tried other tactics. Women stand by their men in hard times, another woman campaigner insisted, and thus would not abandon Hoover in $1932 .{ }^{29}$

Of course, many women (and men as well) did abandon Hoover. As a farm state, Iowa had been hit hard by the Great Depression. Farm income in Iowa dropped from almost $\$ 736$ million in 1929 to about $\$ 311$ million in $1932 .^{30}$ Many Iowans blamed their problems on the failure of the United States to adopt measures that would support the prices of agricultural products. The July bulletin of the Tama County Republican Women's Club, on the other hand, insisted that the depression was a result of the "systematic shrinkage" of important markets for American goods due to the Russian Revolution. Consequently, the bulletin's author argued, Republican women needed to be prepared to fight the spread of Communist propaganda at home in Tama County. Although it is not clear what 'propaganda' the bulletin referred to, the concern about Communist influences suggests that the depression did not nurture in Tama County Republican women a sympathy for radical experiments. ${ }^{31}$

28. Press release, ca. October 1932, Hyatt Report file, box 269, Presidential Subject files, Herbert Hoover Papers.

29. "Nebraska Women Have Faith in Hoover," press release, 14 September 1932, ibid.

30. Philip A. Grant, "The Presidential Election of 1932 in Iowa," Annals of Iowa 44 (1979), 549-50, n. 37.

31. Ella Taylor, "Excellent Club Material," Traer Star-Clipper, 17 July 1931, Tama County Republican Women Scrapbook. Other patriotic women's organizations defined "Communist propaganda" very broadly to include activities by pacifist and progressive women's organizations. See the articles by Francesca Morgan and Kim E. Nielsen in this issue. It is plausible that Tama County Republican women held similarly broad understandings of what constituted Communist-inspired activity. 
Some Iowa farm women, however, did respond to their hardships by participating in radical political activities, such as those of the Farmers' Holiday movement. In the summer of 1932, Farmers' Holiday women in western Iowa worked with men to blockade roads to prevent the delivery of farm products. They hoped their efforts would force up prices and secure what seemed to them a more just economic relationship between farmers and other producers. ${ }^{32}$ Tama County Republican women's clubs responded to hard times differently. In March 1932, for example, one club sponsored talks on the "High Spots of Hoover's Administration" and on the benefits of modern, preventive approaches to the problem of poverty. ${ }^{33}$

Tama County Republican women were not oblivious to the hard times that many Iowans faced during the depression. At the March 1932 meeting publicized by Taylor in her newspaper column, clubwomen emphatically dispelled the "repeated assertions" that there was no poverty in Tama County by noting that the county had paid more than $\$ 61,000$ in poor relief in $1931 .{ }^{34}$ Yet clubwomen's fears of radicalism and their apparently more secure economic position meant that, while Holiday women participated in direct actions intended to force changes in economic relations, Republican clubwomen applauded from the sidelines the Hoover administration's more conservative approaches to the crisis. Several years later, when relief and recovery projects engineered by a Democratic administration meant higher taxes and a stronger role for the federal government in managing the economy, Republican women in Tama County would be outspoken in their opposition.

Republican clubwomen who supported Hoover in 1932 were a minority in Iowa. Farmers in the traditionally Republican state had already begun to turn away from the GOP in $1928 .{ }^{35}$ By

32. See Leslie Taylor, "Femininity as Strategy: A Gendered Perspective on the Farmers' Holiday," Annals of Iowa 51 (1992), 252-77.

33. "County G.O.P. Women Lay Campaign Plans," Traer Star-Clipper, 4 March 1932, Tama County Republican Women Scrapbook.

34. Ibid.

35. This idea is explored in Fite, "Agricultural Issue in the Presidential Campaign of 1928," 653-72. 
1932, their rate of defection had become decisive. Democrat Franklin Roosevelt won all but six Iowa counties that year in his defeat of Hoover, marking the first time since the formation of the Republican Party that the state had cast a majority of its votes for the Democratic presidential candidate. Of Tama County's thirty precincts, Hoover carried only six (including Traer and Toledo). In a state that had elected only one Democratic governor since the 1850 s, Iowa Democrats elected not only a governor, but a senator, six out of nine congressmen, and 60 percent of the state legislature. ${ }^{36}$ Nationally, the Democrats overwhelmingly won both houses of Congress in a landslide victory that ushered in an era of Democratic dominance. It was a profoundly discouraging time to be a Republican in Tama County, in Iowa, and throughout the country.

Not surprisingly, then, Tama County Republican Women's Club activities slackened between 1933 and 1935. In attacking the New Deal at a time when many hard-hit Iowans supported Roosevelt's policies, Republican clubwomen were fighting an uphill battle. ${ }^{37}$ Even in Traer, one of the most steadfastly Republican parts of the county, the local club stopped holding regular meetings, and its membership dropped to a mere 25 faithful. ${ }^{38}$ Yet some GOP leaders continued to see hope in a women's organization. There was still a potential base for Republican women's clubs among the women who previously had identified with the GOP, who had been less affected by hard times than other Tama County residents (the majority of whom voted for Roosevelt in 1932 and 1936), and whose political sensibilities rendered them sympathetic to attacks on the New Deal.

36. "Election Reflections," Traer Star-Clipper, 15 November 1940, in Tama County Republican Women Scrapbook; Grant, "Presidential Election of 1932 in Iowa," 549.

37. New Deal legislation such as the Agricultural Adjustment Act and the Farm Credit Act of 1933 were popular, as were federal projects that surfaced and resurfaced Iowa roads and provided electricity to rural areas. From 1934 to 1938 , cash farm income in Iowa was approximately double what it was in 1932. Nonfarming Iowans also benefited from New Deal relief efforts such as the Federal Emergency Relief Administration and the Civil Works Administration. Jones, "The New Deal Comes to Iowa," 24-26.

38. Ella Taylor, "Traer Republican Women's Club," Traer Star-Clipper, 7 October 1938, Tama County Republican Women Scrapbook. 
Taylor and Banks continued to try to hold together their women's organization after Roosevelt's victory. At a time when the Republican Party was deeply troubled and divided, women's clubs were one of the few places where the party had a grass-roots presence. While the official state and county Republican committees essentially shut down between elections, the strongest Republican women's clubs continued their efforts during off years.

Taylor distinguished between the duties of Republican women's clubs and the women's division of the county Republican Central Committee. The clubs were permanent organizations holding regular meetings between campaigns. Their purpose was to "interest their members in the public questions of the day, to acquaint them with the candidates for public offices and to arouse enthusiasm in getting their members to vote on election day." The women's division of the county Central Committee was responsible for organizing get-out-the-vote campaigns during election seasons. The two organizations worked "in close harmony," according to Taylor. Indeed, the leadership of the two organizations overlapped, and the goals of each reinforced the other. Getting out the women's vote at election time would be facilitated, Taylor hoped, by the women's clubs' efforts to educate and interest women in political issues during the interim years. ${ }^{39}$

In 1934 Iowa National Committeewoman Martha McClure began working with the Iowa Republican State Central Committee to develop the potential of the club movement. Nine women members of the State Central Committee were delegated to establish GOP women's clubs in their respective districts. ${ }^{40}$ These early clubs proved unstable, however, at a time when the Republican Party generally was unpopular. After statewide Republican defeats in 1934, many of the newly formed clubs disbanded.

39. Ella Taylor, "Republican Women's Activities," Traer Star-Clipper, 12 August 1932, in Tama County Republican Women Scrapbook.

40. Harriet Ballard, "The Republican Women's Club Movement in Iowa," [1964], pamphlet in Scrapbook, 1963-1964, box 1, ICRW records. Ballard, one of those nine women, represented the Second District (newly formed under redistricting which had reduced the number of Iowa's congressional districts from 11 to 9 ). 
Organization remained the strongest in the Third District, home of the original Tama County club. In September 1936, in an attempt to consolidate efforts in preparation for the November elections, representatives of clubs from six counties of the Third District (led by club movement veterans Banks and Taylor) met in Marshalltown and formed the Third District Federation of Republican Women's Clubs. Ella Taylor, while claiming no ambition for the post, was elected president. ${ }^{41}$ For their part in the campaign, women in Tama County sponsored a candidate's night that focused on municipal elections, numerous public meetings for the discussion of election issues, and large Republican rallies attended by candidates for national and state offices. ${ }^{42}$ Taylor no longer portrayed clubs as merely priming women for mobilization as voters. She now saw clubs as providing the party with confident and able campaign workers who themselves would mobilize others. ${ }^{43}$

In spite of the women's efforts, however, Republican senatorial candidates Barry Halden and Lester Dickinson, as well as presidential candidate Alfred Landon, suffered defeat in 1936. Yet Roosevelt's victory in Iowa was less decisive than it had been in 1932, and Dickinson, an outspoken critic of the New Deal, lost only narrowly to Democrat Clyde Herring. ${ }^{44}$ Ella Taylor, for one, was ready to give organized Republican women substantial credit for the gains the party was making. The greatest value of Republican women's clubs, according to Taylor, was that dur-

41. "Third District Republican Women's Club Formed," clipping, ca. October 1936; "Third District Women Organize," clipping, 23 October 1936; Ella Taylor, "A New Organization," Traer Star-Clipper, 6 November 1936, Third District Republican Women Scrapbook.

42. "'Candidates Night' in Traer Next Tuesday," Traer Star-Clipper, 20 March 1936; "County G.O.P. Rally at Dysart Monday," clipping, 31 July 1936; "G.O.P. Rally to Be Held Wednesday at Traer Opera House," Traer Star-Clipper, 23 October 1936, Tama County Republican Women Scrapbook.

43. Ella Taylor, Speech, Grundy Center, 8 June 1937, History Book 1937-1956, box 1, ICRW Records.

44. Roosevelt received 55.5 percent of the Iowa vote in 1936 , compared with 60 percent in 1932. Jones, "The New Deal Comes to Iowa," 28-32. Charges that the New Deal represented what Republican Lester Dickinson called an "utterly alien social philosophy" apparently were having an impact, especially among white collar voters and farmers. Dickinson, quoted ibid., 28. 
ing the off years between elections clubs kept "the machinery ... oiled and the political fires burning. Thus no time is lost in building up a new machine and enrolling new workers. ${ }^{\prime 45}$

The problem of overcoming women's lack of interest in political questions continued to vex leading Republican women, however. Organizing Republican women in the mid-1930s was especially difficult. Leaders first had to identify women who were willing to "creep out of the debris" and "wear a Republican label. ${ }^{\prime 46}$ In this regard, the task of mobilization in the 1930s was considerably more difficult than it had been in 1928. But not all of the obstacles to mobilization were new. A decade-anda-half after gaining the right to vote, many of those women whose political leanings were Republican still were skeptical of the act of voting; even more did not consider sustained partisan activities to be appropriate or compelling. The Tama County Republican Women's Club tackled the problem of mobilizing apolitical women to work for an unpopular party by presenting women's involvement with Republican politics as respectable, inviting, and urgent.

\section{IN ORDER TO PROMOTE WOMEN'S PARTICIPATION} in Republican Party politics, women activists fashioned a distinctive female partisan political culture in Iowa's small towns. These activists often saw education as the key to this process. Many women were interested in politics, Ella Taylor asserted in 1937, but did not participate because "they [felt] they [did] not understand the issues at stake. ${ }^{147}$ Republican women's clubs, like earlier study clubs, promised informal, unthreatening discussions of issues (with a partisan tilt) where women could freely ask questions without fear of embarrassment. Yet convincing stay-at-home Republican women to become politically active involved more than educating them about voting procedures and Republican principles. Three additional strategies helped

45. Ella Taylor, Speech, Grundy Center, 8 June 1937, History Book 1937-1956, box 1, ICRW Records.

46. Ella Taylor, Speech at Sixth District meeting in Des Moines, 1938, ibid.

47. Ella Taylor, Speech at First District meeting, 1937, ibid. 
to create a partisan culture that was welcoming to women. First, the clubs linked partisanship to social networks and activities that already were familiar to the women they targeted. Second, the leaders of the club movement emphasized that partisan political activity was the proper focus of an urgent patriotic crusade that women needed to lead. Finally, club leaders consistently contrasted female courage and success in defense of Republican partisanship with male cowardice and ineffectiveness. In its emphasis on education, civic responsibility, and women's moral role in reforming society, Iowa Republican club activity in the 1930s fit into a long tradition of women's voluntarism.

The leaders of the club movement drew the core of their membership from existing social networks. During these early years, clubwomen made little effort to persuade non-Republicans to join the cause, but rather focused on activating those apolitical women they already knew or believed to be Republicans. These might be wives of prominent Republicans or business men or women known through other club work. Many potential Republican women also belonged to patriotic (but nonpartisan) organizations such as the American Legion auxiliary. Equating partisanship with patriotism was an important tactic Taylor used to persuade women to take the partisan plunge.

Using existing social networks was a common way for women's social clubs to organize. For a political organization, however, this method was more problematic. GOP clubwomen reinforced a narrow definition of "women" and "women's interests" that conformed to their own social and economic status and political identity: by organizing through social networks, the Republican club movement effectively limited its members to women who were comfortable socializing with each other.

Within these recruitment limits, the strategy for building membership combined familiar social activities with partisan politics. Meetings were held in parks, libraries, homes, and churches, in contrast to the proverbial "smoke-filled rooms" associated with party politics in the past. It was important to have regular meetings where something noteworthy took place that could be reported in the local newspaper. This might in- 
volve bringing in a speaker or a candidate, staging a debate, or having a local musical group perform. To compete with other women's groups (including bridge clubs and civic organizations), the programs needed to be interesting, politically informative, and "interspersed with fun and play." 48

Yet Ella Taylor, at least, did not view partisan club work as equivalent to other contemporary women's voluntary associations. After the 1936 elections, she asked an audience of women, "Are we [now] going to turn back to our club work, our social life, and forget all about our high resolves as pertains to our duties of citizenship?"49 Taylor admonished her audience to continue the serious work of politics after the election. She insisted on a rhetorical separation between "political" and "social" activities while recognizing that social elements were important to attracting women to political activity.

Framing politics as an urgent, women's crusade also was central to Taylor's efforts to mobilize Republican women. Republican organizers commonly assumed that many women with Republican leanings did not believe politics to be their business. Therefore, women would not mobilize unless they believed that a real crisis was at hand, the solution to which demanded their political activism. In 1928 Republican women leaders had emphasized the moral issue of prohibition. In the mid-1930s, it was the New Deal that was the crisis. If only more women knew the truth about the "perils that threaten America," Taylor emphasized, they would be "roused to the danger" and called to action. ${ }^{50}$

These dangers included what Taylor described as Roosevelt's socialistic economic policies, exorbitant taxes, the threat of Communism, the immorality of young people, and the neglect of the nation's crime problems. All of these problems,

48. Ella Taylor, Speech, Grundy Center, 8 June 1937, ibid.

49. Ella Taylor, "Value of Republican Women's Clubs," October 1936, ibid. Taylor raised similar concerns after Republican successes in 1938. Ella Taylor, "In Again Out Again," Traer Star-Clipper, 18 November 1938, Third District Republican Women Scrapbook.

50. Ella Taylor, Speech at Fourth District meeting, ca. 1938, History Book 1937-1956, box 1, ICRW Records; Taylor, "In Again, Out Again." 
Taylor emphasized, were "a direct menace to our homes," and all were at least loosely connected to New Deal Democrats. ${ }^{51}$ Taylor clearly intended her message to resonate with her audience of church-going, patriotic wives and mothers. She repeatedly depicted women's potential for righteous outrage as a powerful force that, if channeled politically, would deliver the country from the New Deal.

Taylor thought women should listen to those who understood that women had a unique mission in combating social evils. J. Edgar Hoover, Taylor told her audience, felt that women were crucial to crime prevention because of the influence they had over children. ${ }^{52}$ Elsewhere she cited a "noted political commentator" as having claimed that "the salvation" of the United States from Communism rested "in the hands of its women." 53 By suggesting that even male leaders recognized the crucial role of women in fighting certain threats, Taylor conveyed an urgency to those listeners who might otherwise have opted for apathy.

As Taylor made clear, women could not rely on men alone to protect the home or the country. According to an unnamed "noted Boston writer" quoted by Taylor in 1937, only Republican women could accomplish victory for the party. New Deal attacks on business had left Republican men so vulnerable that they were "forced to give the best of themselves to their own financial interests." Women were the only ones with the time and the strength to devote to saving the country from the tyranny of the New Deal-from the "coercion of business and labor [and the] regimentation of agriculture and industry." ${ }^{\prime 54}$ Another Iowa clubwoman later recalled that businessmen from her district in the mid-1930s had been so concerned that their

51. Ella Taylor, Speech, ca. 1937; idem, Speech at Third District Meeting, 1937; idem, Speech, ca. 1938, History Book 1937-1956, box 1, ICRW Records.

52. Ella Taylor, Speech at Third District meeting, ca. 1937, ibid. Taylor stated that Hoover had made the remarks to which she referred before an audience of women in Kansas City. She did not state when the speech occurred.

53. Ella Taylor, Speech at Fourth District meeting, ca. 1938, ibid. See also idem, "First Meeting a Success," Traer Star-Clipper, 29 October 1937, Third District Republican Women Scrapbook.

54. Ella Taylor, Speech, ca. 1938, History Book 1937-1956, box 1, ICRW Records. 
Republican identity would be harmful to their businesses that they "forbade their wives to join any partisan organization." The women who had defied the concerns of their husbands and embarked on a crusade to build the GOP therefore deserved praise. Club leaders celebrated women who overcame resistance and skepticism to pursue Republicanism in the thirties, and often suggested that women were becoming more zealous partisans than men. That zeal was nurtured through anecdotes about women's partisan courage on behalf of an urgent crusade against New Deal threats, told in settings that resembled traditional women's clubs.

Taylor believed that Republican women's clubs deserved substantial credit for keeping the party alive in the thirties. Prominent Republican men often echoed such claims. But how would appreciation for women's role in "keeping the political fires burning" during the dark days of Democratic dominance affect the party as it returned to majority status in the state?

THE REPUBLICAN WOMEN'S CLUB MOVEMENT received a boost in 1938 when Republican victories in Iowa and across the country indicated that the party could be rejuvenated. ${ }^{56} \mathrm{~A}$ three-month strike by Maytag Company workers in Newton, Iowa, and the charges of "New Deal radicalism" that followed apparently undermined the coalition of Iowa farmers and workers that had supported Roosevelt's reelection in 1936. In the 1938 mid-term elections, Republican George Wilson was elected governor, and Republicans regained control of the state legislature and the Iowa congressional delegation. In Tama County, Wilson carried not only stubbornly Republican precincts (such as Traer and Toledo) but won the entire county by a small margin. Speaking to an audience of both men and women in Toledo, Lieutenant Governor Bourke Hickenlooper declared that the

55. Ballard, "Republican Women's Club Movement in Iowa." Harriet Ballard was from Iowa's Second District. See also Ella Taylor, Speech to Sixth District meeting, 1938, History Book 1937-1956, box 1, ICRW Records.

56. Nationally, in 1938, Republicans gained six seats in the Senate and eighty in the House. Nicol C. Rae, The Decline and Fall of the Liberal Republicans from 1952 to the Present (New York, 1989), 29. 


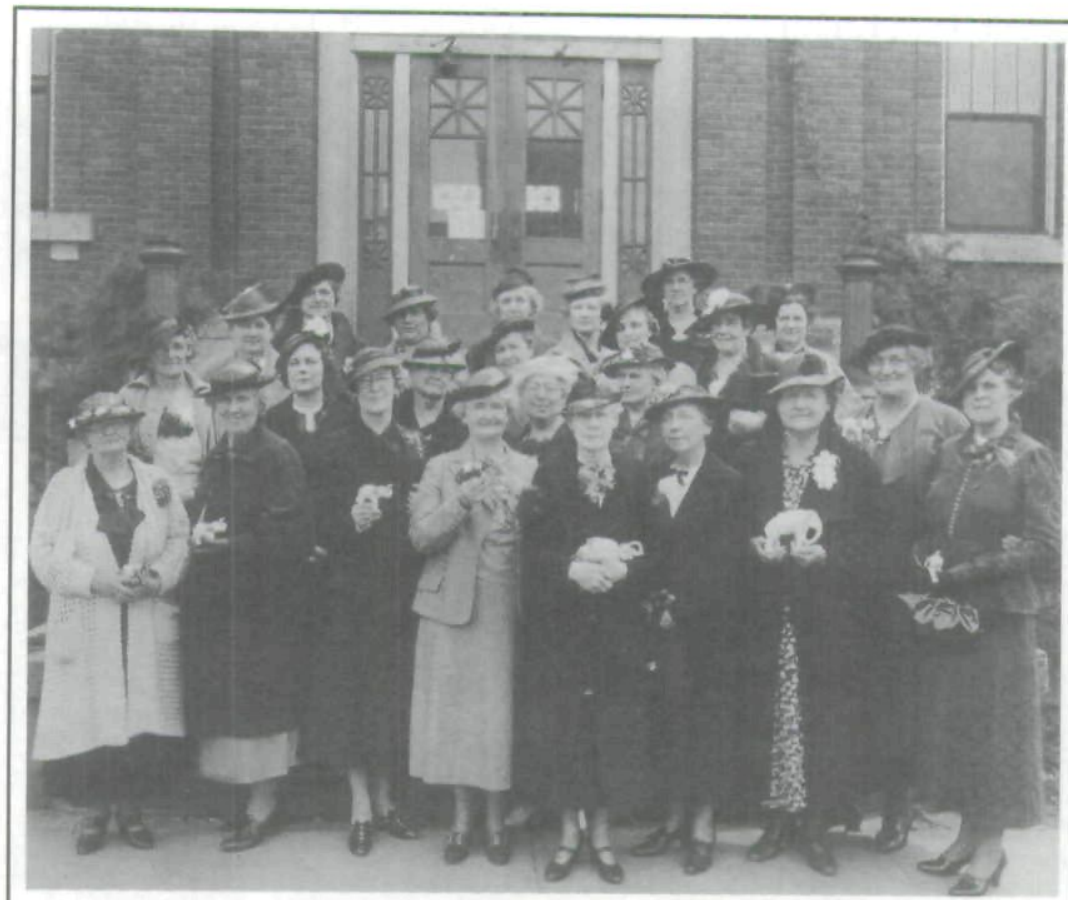

Holding miniature elephants, the board and committee members of the Third District Federation of Republican Women's Clubs pose in May 1937 on the eve of the Republican Party's return to majority status in Iowa. Ella Taylor stands front and center. Immediately to the right are Frances Hemsworth and Mae Banks. Photo courtesy Joyce Wiese.

1938 "return of the republicans to the state of Iowa [had been] due to the women of the party and the laurels rest securely on their shoulders. ${ }^{157}$

The 1938 victories seemed to provide a catalyst for the statewide development of a more stable Republican women's club movement. Ella Taylor, who had traveled the state helping to form district-wide federations, had long promoted the idea of a statewide federation. The idea also was encouraged by na-

57. Jones, "The New Deal Comes to Iowa," 33-35; "Election Reflections," Traer Star-Clipper, 15 November 1940, in Tama County Republican Women Scrapbook; "Hickenlooper Hits at 'Fifth Column' New Deal Tactics," Cedar Rapids Gazette, 29 May 1940, ibid. 
tional leaders in the process of forming a nationwide federation of GOP women's clubs. In 1939 representatives from 62 Iowa clubs met in Des Moines to create the Iowa Council of Republican Women (ICRW). The delegates present elected Frances Hemsworth of Waterloo president by a margin of three votes over Ella Taylor. ${ }^{58}$ Taylor reportedly was "keenly disappointed" by this defeat. Hemsworth's decision not to offer Taylor any appointment within the organization (perhaps because she wanted to distribute leadership throughout the state) only heightened Taylor's disappointment. Taylor did remain a supporter of the state council. Yet as late as 1943 her Third District Federation was not paying dues to the state organization, arguing that since the Third District had been well organized before the state council, the latter had nothing to offer the Third District. ${ }^{59}$

At its first meeting, the ICRW unanimously voted to affiliate with the recently formed National Federation of Women's Republican Clubs (NFWRC). The NFWRC had been organized in 1938 by members of the Republican National Committee as an umbrella organization for the hundreds of GOP women's clubs across the country. This was part of an effort to both stimulate and influence support for the party at the grass roots. The ICRW modeled its goals after those of the National Federation;

58. Des Moines Register, 15 June 1939. Hemsworth had been vice-president of the Third District Federation, which sent her as its delegate to the National Federation of Women's Republican Clubs organizational meeting in Chicago in the fall of 1938. Iowa had not yet formed its own state organization, so Hemsworth and other representatives from Iowa attended the meeting as observers, not as participants. Ella Taylor, "National Federation of Republican Women," Traer Star-Clipper, 21 October 1938, Third District Republican Scrapbook.

59. Marjory Roberts to Marion Martin, ca. July 1939; Ella Taylor to Marion Martin, 21 July 1939, box 5, NF-1(a) Iowa-Affiliated Clubs "2"; Frances Hemsworth to Marion Martin, 22 May 1941; Marjory Roberts to Marion Martin, 21 July 1943, box 5, NF-1(a) Iowa - Affiliated Clubs "1," National Federation of Republican Women Records, Dwight D. Eisenhower Library, Abilene, KS. Competition among Republican women leaders for recognition created organizational problems in several states, resulting in bitter factional divisions that occasionally endured for years. Sometimes, as in California and Florida, these conflicts were replications of existing factions within the state Republican Party itself. In others cases, such as in Oregon, the origins of the rivalries seem to have been more explicitly personal. See "California," "Florida," and "Oregon" files in boxes $1,3,12,13,16,17$, and 19, ibid. 
set dues at five cents per member; and established five committees made up of a member from each of Iowa's nine congressional districts. ${ }^{60}$ Thus, in eleven years, the Iowa Republican women's club movement had grown from 56 women in Tama County to a network of clubs across the state linked to each other as well as to a national umbrella organization.

As part of a larger organization, individual Republican clubs had access to national study materials and monthly bulletins produced by the ICRW's legislative committee. Clubs could also better coordinate their activities and be more effective in their campaign work. By 1941, 92 of Iowa's 99 counties had clubs represented in the ICRW, and more than fifteen thousand women were members of clubs further organized by district and county. ${ }^{61}$ With federation, Republican women's clubs had the potential to move from being isolated study groups to tightly organized recruitment centers for party volunteers and voters.

Yet President Hemsworth indicated even greater ambitions for an organization of Republican women. During a June 1939 speech to the Third District Federation of Republican Women, she insisted that women already had served their political "apprenticeship" by "ringing doorbells in the 'Get Out the Vote' campaigns." It was time to turn those tasks back to the men. Now, Hemsworth contended, Republican women should be demanding a role in the development of public policy. ${ }^{62}$

Reporting on Hemsworth's remarks in the Star-Clipper, Taylor sarcastically questioned whether "the men ever [had done] such menial tasks in any election. ${ }^{163}$ Certainly women's association with these "menial tasks" would not diminish. In the following years women's organizations continued to sponsor

60. The goals established by the ICRW at the Des Moines meeting were to foster party loyalty; to promote the party's ideals; to facilitate cooperation among Republican women's clubs; to support the policies of the RNC and the Iowa SCC; to serve as an information broker; to help elect Republicans; and, in general, to promote freedom, equality, and justice. "Twenty-two Years of the Iowa Council of Republican Women," box 2, ICRW Records.

61. Ibid.

62. Ella Taylor, "Organization Needed," Traer Star-Clipper, 16 June 1939, Tama County Republican Women Scrapbook.

63. Ibid. 
local candidate forums, debates, and speeches by state and national Republican leaders. Women's organizations staffed tables for candidates at county fairs and conducted precinct surveys and registration drives. Male leaders consistently acknowledged the importance of women's work to the party. "The women's groups were never more alert and perhaps never stronger," according to an Iowa Republican Party strategy document from 1952. "The value of this strength can scarcely be overestimated." ${ }^{\prime 4}$

But these acknowledgments did not translate into the access to decision making or to the political appointments that Republican women's leaders sought. By the 1950s, Hemsworth's hopes that Republican women would move into policy-making roles had not been realized. The ICRW leadership, in a bulletin to its members, expressed frustration with the club strategy for entering partisan politics, complaining that women had been relegated to ancillary positions in the party. The ICRW charged that the male party leadership in Iowa had kept women out of politics and thus forced them into club activity as their only arena of civic service. Women, the ICRW further argued, had failed in their duties as citizens by accepting this marginal role. But men also had failed in their own civic duties by focusing exclusively on politics and business and not "integrating themselves into fields of other interests. ${ }^{\prime 65}$ Iowa GOP club movement leaders in the 1950s correctly observed that there were limitations in dividing party politics into men's and women's spheres.

IF DIVISION BY GENDER limited women's role in party politics, that division earlier had been crucial in enabling women to enter party politics at all. The Tama County GOP women's club movement had provided a way for Republican women to ease into the masculine world of party politics by offering a

64. Draft copy of "Plans for 1952," ca. May 1952, box 10, King Palmer, executive director of the Republican State Central Committee, 1951-52, Schramm Family Papers; 1954 Speech Kit, box 3, "Correspondence," Don C. Pierson Papers, Special Collections, University of Iowa Libraries, Iowa City.

65. ICRW, "Flash Bulletin," 1953, Women in Political Service 1953-1956 file, box 6, Anna Lomas Papers, Iowa Women's Archives, University of Iowa Libraries, Iowa City. 
partisan political culture that embraced women's organizational styles, linked partisanship to popular understandings of women's civic and moral responsibilities, and confirmed women's importance to politics. In their clubs, Republican women nurtured an identification with the Republican Party that fused with their identity as women and as citizens. The movement's growth indicates that, as a means of developing partisanship among women, the club movement had been a success.

The work of groups such as the Tama County Republican Club was also an important factor in partisan political activities losing their associations with masculinity and male identity. ${ }^{66}$ Club activities were not restricted to women, but reached out to the broader Republican community. In addition to women's club meetings themselves, clubs sponsored community-oriented events where they combined partisan cheering with political education, wholesome entertainment, and family socializing. Women contributed significantly to Republican meetings as attendees and speakers, and also as organizers who defined agendas and formats. For example, Republican women's clubs, according to Taylor, originated the custom of holding pre-primary candidate forums where voters could acquaint themselves with all those running for local office. ${ }^{67}$ Finally, women volunteers became crucial to registration and get-out-the-vote drives. Women had gradually taken over the grass-roots work of party politics - the social, educational, and recruitment activities that gave the party a local face. By bringing women to the center of these activities, Republican clubwomen helped reshape the local experience of partisan politics in small-town Iowa.

In bringing more women into the center of party decision making, however, the club movement had less of an impact. In the smoke-filled rooms associated with nineteenth-century (male)

66. Woman suffrage and women's partisanship contributed to the weakening of the importance of partisanship to male identity but did not cause it. This process was already under way as a result of the changing nature of politics. By the 1920s, politics placed more emphasis on interest groups such as professional associations and less on party organizations. Testi, "Gender of Reform Politics," 1525.

67. Ella Taylor, "Candidate Night in Traer," 29 May 1936, Traer Star-Clipper, Tama County Republican Women Scrapbook. 
politics, political decisions were made and political debts were incurred. In the libraries, kitchens, and fairgrounds that women claimed as political spaces, they were not. Those decisions and debts still were negotiated largely without women's input. As a means for women to gain significant access to power and influence within the Republican Party, the club movement was a failure.

That failure did not elude Ella Taylor. After the 1938 rebound of the Iowa GOP, Taylor charged that the party had overlooked key women in distributing patronage. In a 1939 column, Taylor lambasted the party leadership for that oversight and threatened to become more confrontational. "Don't these dear men yet realize that women are like cats?" she wrote. "They purr around for a while, but if that doesn't bring them a saucer of milk they later show their claws. Maybe we are nearing the clawing stage." ${ }^{18}$ The clawing stage never materialized. Iowa Republican women continued to complain about the party's failure to live up to its rhetoric about the importance of women to party successes. But party loyalty, nurtured through the club movement, restrained public expression of those criticisms: to complain too openly could help the Democrats. The separate partisan culture that eased women into the party by serving as a bridge between women's traditional organizations and party organizations ultimately proved to be an end in itself. The club movement had developed Republicanism among women but had not integrated Republican women into their party: it had left them at the margins.

68. Ella Taylor, "Ingratitude," Traer Star-Clipper, 30 June 1939, Third District Republican Women Scrapbook. 
Copyright of Annals of Iowa is the property of State of Iowa, by \& through the State Historical Society of Iowa and its content may not be copied or emailed to multiple sites or posted to a listserv without the copyright holder's express written permission. However, users may print, download, or email articles for individual use. 